\title{
COMPARISON OF CARDIAC MAGNETIC RESONANCE AND CARDIAC ULTRASOUND IMAGING FINDINGS IN CONGENITAL AND ACQUIRED HEART DISEASES
}

\author{
Serinsoz Serdar, ${ }^{1}$ Akturk Remzi, ${ }^{2}$ Bayramoglu Sibel ${ }^{3}$ \\ ${ }^{1}$ Istanbul Safa Private Hospital, Istanbul, Turkey \\ ${ }^{2}$ Istanbul Gelisim University, Istanbul Turkey \\ ${ }^{3}$ Istanbul Sultan Abdulhamid Han Training and Research Hospital
}

Primljen/Received 03. 05. 2020. god.

Abstract: Objective: Nowadays, non-invasive methods are emerging in the evaluation of cardiovascular diseases. The aim of this study was to determine the diagnostic performance of cardiac magnetic resonance (CMR) imaging and cardiac ultrasound imaging (Echo) in cardiac patients diagnosed with Echo previously.

Methods: In total of 32 various cardiac patients with Echo findings including congenital and acquired heart pathologies who applied to our clinic were included in the study. The distribution of cardiac pathologies including valve dysfunctions, right and left ventricular wall lesions and movement disorders, atrioventricular hypertrophy, septal defect, pericardial effusion-mass, additional congenital or acquired vascular pathologies and additional thoracic pathology, age and gender correlations were determined. The CMR and Echo findings were compared statistically.

Results: It was found that $12(37.5 \%)$ of the individuals were female, 20 (62.5\%) were male, aged between 6 and 80 years with an average age of 29.9 years. The cardiac parameters were positive in 27 (84.4\%) patients according to Echo and were positive in 22 (68.8\%) patients according to CMR. There was no statistically significant correlation between CMR and Echo for cardiac pathology detection rates $(\mathrm{p}>0.05)$.However, only 18 out of 22 patients who were positive on CMR were positive on Echo. CMR was superior in detecting congenital cardiac pathologies.

Conclusion: Echo has a diagnostic advantage and in general, CMR and Echo findings overlap in cases with valve dysfunctions, ventricular wall motion disorders, and hypertrophy, whereas we found that Echo findings were insufficient for diagnosis of congenital heart pathologies.
Prihvaćen/Accepted 10. 06. 2020. god.

Key words: cardiac magnetic resonance, echocardiography, heart diseases, comparison.

\section{INTRODUCTION}

Heart diseases are among the most common pathologies worldwide and responsible for $31 \%$ of all deaths in the world (1). In our country they are also among the leading causes of mortality and morbidity, and according to Turkish Statistical Institute 2010 data, the most common early causes of death are cardiovascular diseases in both sexes (2). Cardiac diseases are four times more common in males than in females and are more frequent in 50-60 year old females and 60-70 year old males (3).

In the evaluation of heart diseases, non-invasive methods are now at the forefront. Cardiac ultrasound imaging (Echo) is the most important method used during follow-up of cardiovascular patients and is a safe and reliable imaging technique for patients. With Echo, proximal aortic wall thickness, diameters, aorta valve structure and their functions can be assessed in detail, while mitral valve pathology, myocardium systolic and diastolic functions can be assessed with both $2 \mathrm{D}$ and M-mod, continuous wave and pulsed wave Doppler ultrasound. Thanks to its different usage modalities, Echo is a guide for surgical complications, morphologic variations, rejection, and allograft vasculopathy (4).

In recent years, studies about cardiac magnetic resonance (CMR) imaging have gained speed because they show tissue features. Various studies are continuing to reduce unnecessary biopsies and coronary angiographies, and for diagnosis of complications and rejection at early stages. CMR has been used increasingly for the evaluation of myocardial diseases (5). 
CMR was used non-invasively to evaluate coronary artery disease, to evaluate cardiac ischemia and determineits prevalence, measure ventricular function, contractile reserve, and image luminal narrowing of the arteries $(6,7,8)$. It also has an important place in congenital heart diseases. Besides the anatomical imaging of the heart's compartments, it can also show atrioventricular morphological evaluation and structural features can be demonstrated. In summary, CMR imaging is useful to distinguish normal and pathological myocardial tissue. The reason for preference is that it does not involve ionizing radiation and is less costly.

The aim of this study is to identify supporting or opposing findings of cases with cardiac pathology proven by Echo and compare with a non-invasive method, CMR which provides additional findings about neighboring anatomic structures, in light of magnetic resonance technology.

\section{MATERIAL AND METHODS}

A total of 32 various cardiac patients with Echo findings including congenital and acquired heart pathologies who applied to our clinic were included in the study. Among the patient groups, cardiac pathologies, valve dysfunctions (aortic, pulmonary, mitral and tricuspid valves), both right and left ventricular wall lesions (noncompaction, trabeculation, UHL/ARVD anomalies) and movement disorders (hypokinesia, movement, acquired), atrioventricular hypertrophy, septal defect, pericardial effusion-mass, additional congenital or acquired vascular pathologies (acquired such as congenital aortic and pulmonary arterial embolisms, strictures and aneurysmal dilatations such as aortic coarctation, dextra malposition, giant eustachian valve) distributions, findings, age and gender correlations with thoracic pathology were included.

The CMR test was performed using a phase sequential coilin a 1.5 T MR device (Siemens, Magnetom Avanto Syngo, Erlangen, Germany). Cine gradient echo T2A long axis, TSE T1A and fat-suppressed T2A short and long axis sequences ( 2 and 4 chamber images), identification of standard cardiac morphology (wall lesions especially ARVD, wall movements, valve lesions, large vessel lesions and congenital anomalies), mediastinal and thoracic pathologies were implemented. In spin-echo sequence routine cardiac examination, TR appropriate to R-R' interval in ECG, TE: 30 msn, section thickness $=8 \mathrm{~mm}$, Matrix: 224 x 224, FOV $=300 \mathrm{X} 400 \mathrm{~mm}$; parameters for sine-cardiac MR examination TR/TE, $3.4 / 1.5$, slip angle $(\mathrm{FA})=45^{\circ}$; sectional thickness $=8 \mathrm{~mm}$, matrix $=224 \times 224$, FOV $=35$ $\mathrm{cm}$ were applied. Patients with myocarditis and cardiomyopathies and myocardial involvement had imag- ing taken 10-20 minutes after intravascular (IV) extracellular contrast agent injection (0.1-0.2 $\mathrm{mmol} / \mathrm{kg}$ ) with late contrast IR images in multiplanar sections. Late contrast imaging used TR/TE, 4.8/1.3, flip angle (FA) 20o, receiver band width $\pm 31.25 \mathrm{kHz}, \mathrm{FOV}=35$ $\mathrm{cm}$, cross section thickness $8 \mathrm{~mm}$, cross sectional area $2 \mathrm{~mm}$ and matrix $256 \times 160$ parameters. Echocardiographic images were obtained in the standard parasternal long and short axis and apical 4 chamber and 2 chamber views utilizing digital Vivid 7 ultrasound equipment with a combined tissue imaging $2.5-4.0 \mathrm{MHz}$ transducer (GE, Milwaukee, WI). At least 3 cardiac cycles were captured at the left ventricular (LV) base, mid papillary muscle level, and apex for wall motion assessment. No intravenous echocardiographic contrast agent was used.

\section{Statistical analysis}

Chi-square and Fisher's Exact Chi-Square tests were used to compare descriptive statistics (mean, standard deviation, frequency), as well as qualitative data when evaluating study data. McNemar test and diagnostic screening tests were used for CMR and Echo evaluations of cardiac pathologies; significance was evaluated as $\mathrm{p}<0.05$.

\section{RESULTS}

The ages of the 32 patients included in the study ranged from 6 to 80 years with a mean age of $29.93 \pm$ 19.80, with 12 (37.5\%) women and 20 (62.5\%) men.

From cardiac parameters, Echo was positive in 27 (84.4\%) cases and CMR was positive in 22 (68.8\%) cases (Tables 1 and 2). Congenital cardiac pathologies were detected in six cases. In 15 (46.9\%) of the cases, valve dysfunction was present. On the right, 4 (12.5\%) of the cases had abnormal ventricular wall motion or structural abnormality. On the left, 9 (28.1\%) of the cases with abnormal ventricular wall motion or structural abnormality diagnosed by CMR. Fourteen of the cases had atrial-ventricular hypertrophy $(43.8 \%)$, and 5 $(15.6 \%)$ of the cases had additional vascular abnormality and nonspecific wall tumors.

There was no statistically significant correlation between cardiac pathology rates on CMR and Echo ( $p$ $>0.05$ ) (Table 1). With the Echo method, $84.4 \%$ of the

Table 1. Distribution of cardiac pathologies according to imaging method

\begin{tabular}{|l|c|c|}
\hline $\begin{array}{c}\text { Cardiac } \\
\text { pathology }\end{array}$ & Positive n (\%) & Negative n (\%) \\
\hline Echo & $27(84.4)$ & $5(15.6)$ \\
\hline CMR & $22(68.8)$ & $10(31.2)$ \\
\hline
\end{tabular}


Table 2. Relationship between CMR and Echo in cardiac pathology

\begin{tabular}{|c|c|c|c|}
\hline \multirow{2}{*}{} & \multicolumn{2}{|c|}{ Cardiac pathology CMR } & \multirow{2}{*}{} \\
\cline { 2 - 3 } & Positive & Negative \\
\cline { 2 - 3 } & $\mathbf{n ~ ( \% )}$ & $\mathbf{n}(\mathbf{\%})$ & \\
\hline Cardiac pathologyEcho & $18(56.3)$ & $9(28.1)$ & \multirow{2}{*}{$\mathbf{0 . 2 6 7}$} \\
Positive & $4(12.5)$ & $1(3.1)$ & \\
Negative & &
\end{tabular}

*McNemar test.

cases received positive diagnosis and with cardiac MR $68.8 \%$ of the cases received positive diagnosis. Of the 22 patients positively diagnosed with CMR, only 18 had the same positive diagnosis in Echo; whereas the other cases were negative in Echo. The sensitivity of CMR was $81.8 \%$ and specificity was determined as $10 \%$. The positive predictive value was $66.67 \%$ and the negative predictive value was $20 \%$. Of the 27 patients who had pathology detected on Echo, only 18 had pathological diagnosis on CMR. Two cases of ventricular septal defect (VSD), one case of left ventricular hypertrophy and one case of tricuspid insufficiency, a total of four, were positive on CMR unlike Echo findings which were all negative (Figure 1). In contrast with the two imaging methods, it was found that Echo findings were inadequate in cases of congenital heart disease, while CMR and Echo findings overlapped in cases with valve dysfunctions, ventricular wall motion disorders and hypertrophy in general.

There was no statistically significant difference between cardiac pathologies according to gender with
Echo findings and CMR findings $(\mathrm{p}>0.05)$. There was no statistically significant difference between the findings of valve dysfunction according to gender $(p>$ 0.05 ). For similar structural features of ventricular wall motion on the right and left according to gender, atrial ventricular hypertrophy, additional vascular abnormalities and non-specific wall tumors, septal defect and additional thoracic pathology findings were not statistically significant $(p>0.05)$.

When both imaging methods were evaluated in terms of age in cardiac pathologies, there was no statistically significant difference between the Echo and CMR findings with age $(p>0.05)$ (Table 3$)$. Similarly, there was no statistically significant difference between the findings of valve dysfunction according to age distribution $(\mathrm{p}>0.05)$ (Table 4).

\section{DISCUSSION}

Cardiac MRI is now an important diagnostic imaging method for detecting congenital and acquired cardiac pathologies. CMR provides more findings incar-

Table 3: Evaluation of cardiac pathologies by age

\begin{tabular}{|l|c|c|c|c|}
\hline \multirow{2}{*}{} & \multicolumn{3}{|c|}{ Age } & \multirow{2}{*}{$*$} \\
\cline { 2 - 4 } & $<\mathbf{1 5}$ & $\mathbf{1 6 - 4 0}$ & $>\mathbf{4 0}$ & $\mathbf{n}$ \\
\cline { 2 - 5 } & $\mathbf{n ( \% )}$ & $\mathbf{n}(\mathbf{\%})$ & $9(100)$ & $\mathbf{0 . 2 8 3}$ \\
\hline Cardiac pathology Echo & $9(81.8)$ & $9(75)$ & $7(77.8)$ & $\mathbf{0 . 7 7 9}$ \\
\hline
\end{tabular}

* Chi square test

Table 4. Evaluation of valve dysfunctions by age

\begin{tabular}{|c|c|c|c|c|}
\hline & \multicolumn{3}{|c|}{ Age } & \multirow{3}{*}{$p^{*}$} \\
\hline & $\begin{array}{c}<15 \text { year } \\
(n=11)\end{array}$ & $\begin{array}{c}16-40 \text { year } \\
(n=12)\end{array}$ & $\begin{array}{c}>40 \text { year } \\
\quad(n=9)\end{array}$ & \\
\hline & n (\%) & n (\%) & n (\%) & \\
\hline Valve Dysfunction & $3(27.3)$ & $6(50)$ & $6(66.7)$ & 0.206 \\
\hline TI & $3(27.3)$ & $5(41.7)$ & $2(22.2)$ & 0.598 \\
\hline AI & $1(9.1)$ & $1(8.3)$ & $1(11.1)$ & 0.976 \\
\hline MI & $2(18.2)$ & $2(16.7)$ & $4(44.4)$ & 0.282 \\
\hline AS & 0 & 0 & $1(11.1)$ & 0.267 \\
\hline
\end{tabular}

* Chi square test (TI: Tricuspid Insufficiency, AI: Aortic Insufficiency, MY: Mitral Insufficiency, AS: Aortic Stenosis) 
diac diseases compared to other methods like echo, scintigraphy or angiography in just a single examination. For evaluation of congenital heart diseases, it ensures important benefits in providing cardiac anomaly imaging and additional information.

MRI shows the anatomical health of the compartment of the heart and evaluates the atrium and ventricle morphologically. In our study, 14 cases of atrial and/or ventricular hypertrophy were present. In addition to showing hypertrophy on MRI, due to real-time and high-resolution imaging of the affected valve functions in cine imaging, progress is being made to obtain important information that willlead to diagnosis and treatment.

Subendocardial perfusion defects, as is well known in acute myocardial ischemia, are the first findings followed by transmural perfusion defects and wall motion disorders. Electrocardiographic changes and angina are relatively late developing findings (9). Cardiac MRI has an important benefit in detecting infarcts. Especially, choosing late contrast sequences provides great benefits on this subject. In studies performed by De Roos et al. late contrast enhancement in the infarct area was confirmed before and after administration of i.v. $0.1 \mathrm{mmol} / \mathrm{kg}$ Gd DTPA2 to 17 days after myocardial infarction. Images are acquired 30 minutes after injection to reveal late involvement (10).

One of the most common clinical methods for detecting perfusion abnormalities is myocardial perfusion single photon emission computed tomography (SPECT). An important advantage of this method is its validity with a large number of multicenter studies. However, it has the disadvantage of having low temporal and spatial resolution, attenuation artifacts and ionizing radiation. Concomitant contrast-enhanced MR angiography provides better diagnostic imaging of myocardial ischemia $(11,12)$.

Another limited imaging method for myocardial blood flow is positron emission tomography (PET). It has some disadvantages like low resolution of subendocardial tissue, difficult to access due to cost and involving ionizing radiation. In addition, the analysis of images is quite time-consuming and complicated. However, evaluation of subendocardial perfusion is much better with cardiac MRI with high temporal and spatial resolution (13). MRI can also be used to visualize complications such as aneurysm formation due to ischemic heart diseases, valvular regurgitation and pericardial effusion. There is a high risk of thrombus formation in these areas, especially due to slowing blood flow in transmural infarcts and aneurysmal areas developing after infarction. Detection of thrombi between the left ventricular apex and endocardial trabeculations may not be easy withtransthoracic echocardiography. Throm- bi can be easily visualized and distinguished from slow blood flow with contrast and cine MR images (14). In one case we could not distinguish thrombus or mass with Echo, then we performed cardiac MRI to image the location, and displacement during the cycle and non-enhancing internal structure and easily demonstrated the thrombi. Unlikemass-thrombus diagnosed with Echo, a giant eustachian valve which is hard to distinguish was diagnosed with CMR in one case. In total, six cases had congenital cardiac pathology; in three of them we detected the diagnostic addition and in the other three, one with Uhl abnormality and two with septal defects, we detected the diagnostic superiority of MRI compared to Echo.

Conventional coronary angiography is still considered the gold standard imaging method forthe coronary arteries. However, CMR angiography is preferred to conventional coronary angiography because of the risk of radiation exposure during operation, being an invasive procedure and complications (15).

In hypertrophic cardiomyopathy cases, the main diagnosis is made by echocardiography. However, CMR provides higher spatial resolution, can easily detect the localization and the damage of the myocardial abnormality (16).

The limits of our study are the inclusion of a certain number of patients with a wide heart disease spectrum. We think that more specific findings and specific pathologies may be obtained if performed with more study groups.

The CMR technique has the capability of presenting a wide range of information in a single study in contrast with echocardiography, scintigraphy and angiography, which are commonly used in the assessment of cardiac pathologies.

\section{CONCLUSION}

Echo has diagnostic advantage andin general, CMR and Echo findings overlap in cases with valve dysfunctions, ventricular wall motion disorders, and hypertrophy, whereas we found that Echo findings were insufficient fordiagnosis of congenital heart pathologies. We believe that in the near future we will eliminate many of the methods used for cardiac pathologies with technological developments that resolve the limitations of the procedure.

Conflict of Interests: The authors declare that there are no conflicts of interest related to this article.

Funding: None

\section{Licensing}

This work is licensed under a Creative Commons Attribution 4.0 International (CC BY 4.0) License. 


\title{
Sažetak
}

\section{UPOREĐIVANJE NALAZA MAGNETNE REZONANCE I ULTRAZVUKA SRCA KOD KONGENITALNIH I STEČENIH SRČANIH BOLESTI}

\author{
Serinsoz Serdar, ${ }^{1}$ Akturk Remzi, ${ }^{2}$ Bayramoglu Sibel ${ }^{3}$ \\ ${ }^{1}$ Istanbul Safa Private Hospital, Istanbul, Turkey \\ ${ }^{2}$ Istanbul Gelisim University, Istanbul Turkey \\ ${ }^{3}$ Istanbul Sultan Abdulhamid Han Training and Research Hospital
}

Uvod: U današnje vreme, za evaluaciju kardiovaskularnih oboljenja, prednost se daje neinvazivnim metodama. Cilj ove studije bio je da se ispita dijagnostički učinak magnetne rezonance srca i ultrazvuka srca kod pacijenata koji boluju od srčanih bolesti, a kod kojih je prethodno utvrđena dijagnoza pomoću ultrazvuka srca.

Metod: Ukupno 32 pacijenta sa različitim bolestima srca, koje su potvrđene ultrazvučnim nalazima, a koja su uključivala kongenitalnu i stečenu srčanu patologiju, bila su uključena u ovu studiju. Distribucija kardioloških oboljenja uključivala je valvularnu disfunkciju, lezije zidova i poremećaje pokreta leve i desne komore, atrioventrikularnu hipertrofiju, septalni defekt, perikardijalnu efuziju, dodatna kongenitalna i stečena vaskularna oboljenja, kao i dodatnu torakalnu patologiju, a ispitivani su i uzrast i pol. Nalazi magnetne rezonance srca i ultrazvučni nalazi srca, su upoređivani statistički.

Rezultati: Utvrđeno je da 12 (37,5\%) ispitanika je bilo ženskog, a 20 (62,5\%) muškog pola, starosti od

\section{REFERENCES}

1. Global action plan for the prevention and control of NCDs 2013-2020..Geneva, World Health Organization. https:// www.who.int/nmh/events/ncd_action_plan/en/

2. Sahan C, Sozmen K, Doganay S, Unal B. Turkiye'de kalp ve damar hastaliklari sikliklar2ndaki degisimin degerlendirilmesi. Turk J Public Health. 2015; 13(1): 62-80.

3. Onat A, Karakoyun S, Akbas T, Karadeniz OF, Karadeniz Y, Cakır H et al. Turkish Adult Risk Factor survey 2014: Overall mortality and coronary disease incidence in Turkey's geographic regions. Türk Kardiyol Dern Arş - Arch Turk Soc Cardiol. 2015; 43(4): 326-32.

4. Sade LE, Muderrisoglu IH. Kalp nakil hastalarinin guruntuleme ile degerlendirilmesi. Turkiye Klinikleri Kalp Damar Cerrahisi-Ozel Konular. 2018; 10(2): 102-8.

5. Yalin K, Guler TE, Sanli S. Cardiac magnetic resonance imaging experience of a newly established cardiology center. Kocaeli Med J. 2018; 7(1): 2-6.

6. Dursun M, Yilmaz S, Yilmaz E, Y1lmaz R, Onur I, Oflaz $\mathrm{H}$ et al. The utility of cardiac MRI in diagnosis of infective endocarditis: preliminary results. Diagn Interv Radiol. 2015; 21(1): 28-33.

7. Danad I, Szymonifka J, Twisk JWR, Norgaard BL, Zarins CK, Knaapen P et al. Diagnostic performance of cardiac imaging
6 do 80 godina, sa srednjom vrednosti od 29,9 godina. Kardijalni parametri bili su pozitivni kod 27 pacijenata $(84,4 \%)$ prema nalazima ultrazvuka srca i pozitivni kod 22 pacijenta $(68,8 \%)$, prema nalazima magnetne rezonance. Nije utvrđena statistička značajnost između MR i ultrazvučnog nalaza srčane patologije ( $\mathrm{p}>$ 0,05). Međutim, samo 18 od 22 pacijenta koji su bili pozitivni na MR, su imali pozitivan nalaz na ultrazvučnom pregledu. Magnetna rezonanca srca se pokazala kao superiornija u dijagnostici kongenitalnih srčanih patologija.

Zaključak: Ultrazvučna dijagnostika srca ima prednosti u odnosu na MR uopšteno govoreći, nalazi ultrazvučnog pregleda srca i MR srca se preklapaju kod slučajeva sa valvularnom disfunkcijom, poremećajem pokreta zidova srčanih komora, hipertrofije, dok je nađeno da su ultrazvučni nalazi nedovoljni za dijagnozu kongenitalnih bolesti srca.

Ključne reči: magnetna rezonanca srca, ehokardiografija, srčane bolesti, upoređivanje.

methods to diagnose ischaemia-causing coronary artery disease when directly compared with fractional flow reserve as a reference standard: a meta-analysis. Eur Heart J. 2017; 38 (13): 991-8.

8. Sachdeva S, Song X, Dham N, Heath DM, DeBiasi RL. Analysis of clinical parameters and cardiac magnetic resonance imaging as predictors of outcome in pediatric myocarditis. Am J Cardiol. 2015; 115 (4): 499-504.

9. Hamirani YS, Kramer CM. Cardiac MRI assessment of myocardial perfusion. Future Cardiol. 2014; 10(3): 34958.

10. Rajiah P, Desai MY, Kwon D, Flamm SD. MR imaging of myocardial infarction. RadioGraphics. 2013; 33(5): 1383412.

11. Salata BM, Singh P. Role of cardiac PET in clinical practice. Curr Treat Options Cardiovasc Med. 2017; 19(12): 93.

12. Rahman H, Ryan M, Lumley M, Modi B, McConkey $\mathrm{H}$, Ellis $\mathrm{H}$ et al. Coronary microvascular dysfunction is associated with myocardial ischemia and abnormal coronary perfusion during exercise. Circulation. 2019; 140(22): 180516.

13. Schwitter J, Wacker CM, Wilke N, Al Saadi N, Sauer E, Huettle K et al. MR-IMPACT II: Magnetic Resonance Imaging for Myocardial Perfusion Assessment in Coronary artery disease Trial: perfusion-cardiac magnetic resonance vs. single-photon emission computed tomography for the detection of coronary artery disease: a comparative multicentre, multivendor trial. Eur Heart J. 2013; 34(10): 77581. 
14. Di Leo G, Fisci E, Secchi F, Ali M, Ambrogi F, Sconfienza LM et al. Diagnostic accuracy of magnetic resonance angiography for detection of coronary artery disease: a systematic review and meta-analysis. Eur Radiol. 2016; 26(10): 3706-18.

15. Neglia D, Rovai D, Caselli C, Pietila M, Teresinska A, Aguade-Bruix S et al. Detection of significant coronary artery disease by noninvasive anatomical and functional imaging. Circ Cardiovasc Imaging. 2015; 8(3): e002179.

16. Hoey E, Elassaly M, Ganeshan A, Watkin RW, Simpson $\mathrm{H}$. The role of magnetic resonance imaging in hypertrophic cardiomyopathy. Quant Imaging Med Surg. 2014; 4(5): $397-$ 406.

\section{Correspondence to/Autor za korespondenciju}

\section{Serinsoz Serdar}

Istanbul Safa Private Hospital

Istanbul, Turkey

email: serinsoz@gmail.com 